\title{
The Effect of Cooling Water Mass Flow Rate Variations on the Heat Pipe Solar Collector Performance.
}

\author{
Abdulsalam D. M.Hassan ${ }^{* 1}$, Rwaa Alaa Hussein ${ }^{* 2}$ \\ ${ }^{1}$ Mechanical Engineering Department, Wasit University, Iraq, abddawood@uowasit.edu.iq \\ ${ }^{2}$ Mechanical Engineering Department, Wasit University, Iraq \\ Submitted: 23/2/2017 \\ Accepted: 9/5/2017
}

\begin{abstract}
The thermal performance of FPHPSC has been studied experimentally and theoretically. The collector consists of copper absorber plate, single glass cover, glass wool insulation and aluminum case. Ten wickless heat pipes of $12.7 \mathrm{~mm}$ inner diameter. The experimental studies of collector performance have been performed on four different CWMFR $(0.03,0.04,0.05$ and 0.06$) \mathrm{kg} / \mathrm{s}$. The relation between the amount of useful heat, instantaneous collector efficiency and solar intensity is discussed. The collector are tested under the climate condition of Kut city (32.6 latitude and 45.7 longitude). It is investigated that the increasing of CWMFR increase the efficiency of the collector. The percentage increase in the efficiency of the solar collector is in order of $(13 \%)$, when the cooling water mas flow rate changes from $0.03 \mathrm{~kg} / \mathrm{sec}$ to $0.06 \mathrm{~kg} / \mathrm{sec}$ at $\left(45^{\circ}\right)$ collector tilt angle. A computer program based on VISUAL BASIC language (version 6) used for the theoretical analysis. The experimental results are in agreement reasonably with the theoretical predictions.
\end{abstract}

Key words: solar collector, flat plate, heat pipe, cooling water mass flow rate.

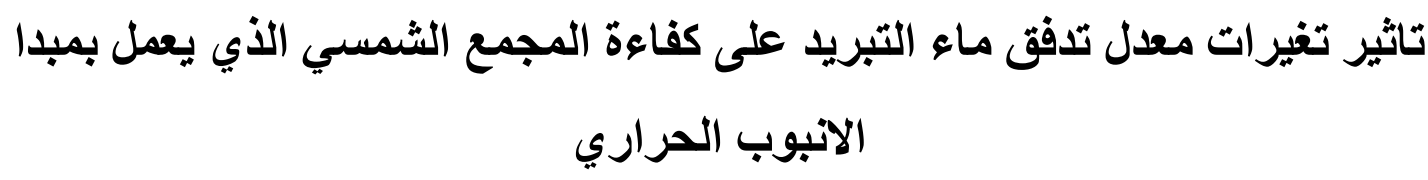

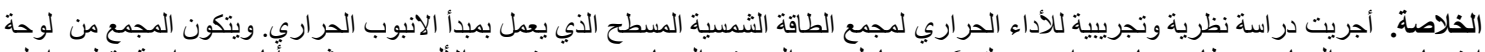

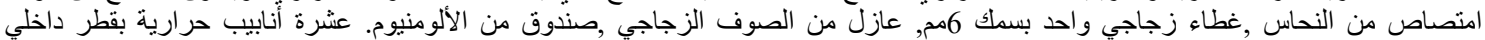

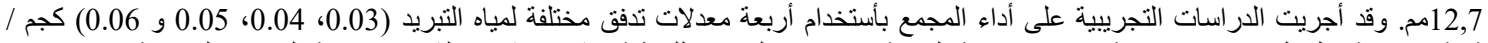

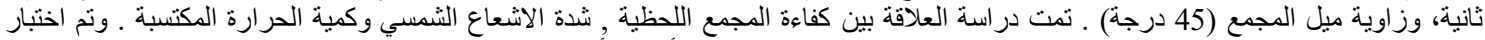

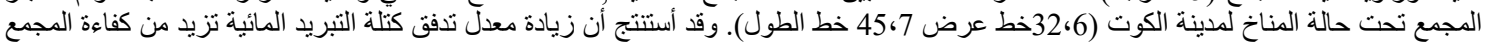

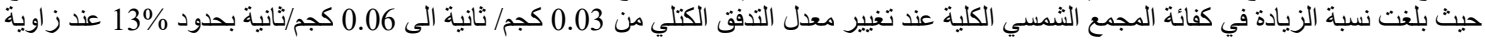

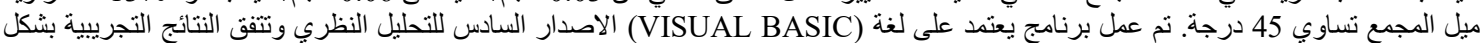

\begin{tabular}{|l|l|l|}
\multicolumn{2}{c}{$\begin{array}{c}\text { Nonmecalture } \\
\text { Latin Symbols }\end{array}$} \\
\hline Symbol & Description & Units SI \\
\hline A & Area & $\mathrm{m}^{2}$ \\
\hline $\mathrm{Cp}$ & Specific heat of water. & $\mathrm{J} / \mathrm{kg} .{ }^{\circ} \mathrm{C}$ \\
\hline $\mathrm{Di}$ & Inner diameter of heat exchanger pipe. & $\mathrm{M}$ \\
\hline do & Outer diameter of heat pipe. & $\mathrm{M}$ \\
\hline $\mathrm{di}$ & Inner diameter of heat pipe. & $\mathrm{M}$ \\
\hline $\mathrm{E}$ & Over-all Effectiveness. & - \\
\hline $\mathrm{Fr}$ & Heat removal factor. & - \\
\hline $\mathrm{G}$ & Gravitational acceleration. & $\mathrm{m} / \mathrm{s}^{2}$ \\
\hline $\mathrm{H}_{\mathrm{t}}$ & Solar insolation on tilted surface & $\mathrm{W} / \mathrm{m}^{2}$ \\
\hline $\mathrm{H}$ & Convection heat transfer coefficient. & $\mathrm{W} / \mathrm{m}^{2} . \mathrm{C}$ \\
\hline $\mathrm{K}$ & Thermal conductivity. & $\mathrm{W} / \mathrm{m} . \mathrm{C}$ \\
\hline $\mathrm{L}$ & Length. & $\mathrm{M}$ \\
\hline$\dot{\mathrm{m}}$ & Cooling water mass flow rate. & $\mathrm{Kg} / \mathrm{s}$ \\
\hline $\mathrm{N}$ & Number of heat pipe. & - \\
\hline ntu & Number of transfer unit for one heat pipe. & - \\
\hline
\end{tabular}




\begin{tabular}{|l|l|l|}
\hline $\mathrm{NTU}$ & Number of transfer unit for $\mathrm{n}$ number of heat pipe. & - \\
\hline $\mathrm{Nu}$ & Nusselt's number & - \\
\hline $\mathrm{Q}$ & Heat transfer rate. & $\mathrm{W}$ \\
\hline $\mathrm{R}$ & Thermal Resistance. & $\mathrm{C} / \mathrm{W}$ \\
\hline $\mathrm{T}$ & Temperature. & ${ }^{\circ} \mathrm{C}, \mathrm{K}$ \\
\hline $\mathrm{T}$ & Thickness. & $\mathrm{M}$ \\
\hline $\mathrm{U}$ & Heat rate transfer coefficient. & $\mathrm{W} / \mathrm{m}^{2} . \mathrm{C}$ \\
\hline
\end{tabular}

Greek Symbols

\begin{tabular}{|l|l|l|}
\hline Symbol & Description & Units \\
\hline $\mathrm{N}$ & Kinematic viscosity & $\mathrm{m}^{2} / \mathrm{s}$ \\
\hline $\mathrm{E}$ & Effectiveness & - \\
\hline$\eta$ & Efficiency & - \\
\hline$(\tau \alpha)$ & Transmissivty-absorptivity product & - \\
\hline
\end{tabular}

Subscripts

\begin{tabular}{|l|l|}
\hline \multicolumn{1}{|c|}{ Symbol } & Title \\
\hline a & Air, ambient \\
\hline a 1 & Absorber for single heat pipe \\
\hline con & Condenser \\
\hline cp & Condenser pipe \\
\hline e & Evaporator \\
\hline ep & Evaporator pipe \\
\hline h & Hydraulic \\
\hline hp & Heat pipe \\
\hline $\mathrm{i}$ & Inlet, inside \\
\hline o & Outlet, outside \\
\hline p & Pipe \\
\hline Theo. & Theoretical \\
\hline $\mathrm{u}$ & Useful \\
\hline w & Water \\
\hline
\end{tabular}

Abbreviations

\begin{tabular}{|l|l|}
\hline \multicolumn{1}{|c|}{ Symbol } & \multicolumn{1}{c|}{ Title } \\
\hline CWMFR & Cooling water mass flow rate \\
\hline HPSC & Heat pipe solar collector \\
\hline FPHPSC & Flat plate heat pipe solar collector \\
\hline Hp & Heat pipe \\
\hline
\end{tabular}

\section{1-Introduction:}


The HP is a device with a very high thermal conductance [1]. The steps of HP development may be began firstly with the introduction of Perkins tubes by Perkins family at the interval from the mid nineteenth to twentieth century [2]. The concept of the HP was conceived by Gaugler in 1942. The HP was independently reinvented by Grover in the early 1960s, that appreciated the important properties of the HP and then series development took place.The HP is characterized by the large quantities of heat rates that can be transported over a considerable distances with small temperature drops, simple construction, exceptional flexibility, easy control and without parasitical pumping power [3].

There are two main types of HPs: wick driven HP and wickless HP.

In [4], developed analytical model based on heat energy balance equations and assuming a steady state condition, to evaluate the thermal performance of wick assisted HP flat plate solar collector Three types of working fluid were examined (acetone, methanol and ethanol). The efficiency and the overall loss coefficient with methanol as working fluid were $70 \%$ and $3.7 \mathrm{~W} / \mathrm{m}^{2} . \mathrm{K}$ respectively, which approached the result carried by Facao [5], acetone performed better as working fluid than methanol and ethanol. In [6], reported an experimental investigation of the thermal performance of two thermosyphons that were especially proposed for flat plate solar collector applications. The first thermosyphon was made of copper smooth pipe. While the second one had the same container except that it was contained a liquid retention structure made of copper helicoidal wire which was inserted in the evaporator section. This structure was introduced to avoid the dry-out limitation (in case of small slope) by increasing the wetted region without increasing the filling ratio and to intend bubble nucleation sits along the evaporator section wall, thus avoiding the geyser boiling phenomena. In [7], examined experimentally a flat plate wickless HPSC with heat exchanger of shell and tube type. The studied parameters were different inlet cooling water temperature, different CWMFR and number of HPs used in the rig. It is also observed that the optimum number of heat pip accommodate with optimum coolant rate is equal to 12 pipes, they resulted in maximum efficiency of the collector. This type of heat exchangers had simplicity in manufacturing, required low cost and gave efficiency curve slope close but higher than that of collector with double pipe heat exchanger. In [8], performed an experimental investigation of a HPSC used for water heating. The experimental study was validated by using numerical model. The results showed that forced convection mechanism give higher efficiency as compared to natural convection mechanism. On the other hand free convection process is free from parasitic power and low system weight. By using cross flow and parallel flow heat exchangers seemed to have no appreciable differences. In [9], presented a study of improving the HP collector by increasing the condenser length of HP .Two evacuated tube HP collectors were manufactured and tested under the condition of Baghdad with the same dimension but variable condenser lengths and fill ratios $(30 \%, 50 \%, 70 \%$ and 90\%). It was concluded that the performance of the system enhanced by increasing the condenser length, optimum fill ratio was $50 \%$.

Key words: solar collector, flat plate, heat pipe, cooling water mass flow rate.

\section{Theoretical Analysis.}


Evaporator section of the HP is heated by the incoming collected solar radiation, therefore, the working fluid inside the HP is evaporated and traveled upward to condenser section where it is condensed .The amount of heat energy transferred by the HP from the evaporator section to the condenser can be written as [10]:

$Q_{h p}=\left(\mathrm{T}_{\mathrm{hp}}-\mathrm{T}_{\mathrm{con}}\right) \mathrm{A}_{\mathrm{hp}} /\left(\sum \mathrm{R}_{\mathrm{hp}}\right)$

$\mathrm{U}_{\mathrm{hp}}=1 / \sum \mathrm{R}_{\mathrm{hp}}$

$\mathrm{R}_{\mathrm{hp}}=\mathrm{R}_{\mathrm{ep}}+\mathrm{R}_{\mathrm{cp}}$

$\mathrm{R}_{\mathrm{ep}}, \mathrm{R}_{\mathrm{cp}}$ can be calculated according to Fourier's low for heat conduction through a cylindrical pipe as follows [11]:

$\mathrm{R}_{e p}=\left(\ln \left(\mathrm{d}_{o} / \mathrm{d}_{i}\right)\right) /\left(2 \pi \mathrm{K}_{p} \mathrm{~L}_{e}\right)$

$\mathrm{R}_{c p}=\left(\ln \left(\mathrm{d}_{o} / \mathrm{d}_{i}\right)\right) /\left(2 \pi \mathrm{K}_{p} \mathrm{~L}_{c o n}\right)$

The amount of heat transferred between the condenser section of a single HP and the cooling water flowing over this section can be calculated as:

$\mathrm{Q}_{\text {con }}=\mathrm{A}_{\text {con }} \mathrm{U}_{\text {con }}\left(\mathrm{T}_{\text {con }}-\mathrm{T}_{i}\right)$

The heat energy transferred through the HP (eq. (1)) is equal to that extracted in the heat exchanger (eq. (6)), thus:

) $\left(T_{h p}-T_{c o n}\right) \mathrm{A}_{\mathrm{hp}} \mathrm{U}_{h p}=\mathrm{Q}_{\text {con }}=\mathrm{A}_{\text {con }} \mathrm{U}_{\text {con }}\left(\mathrm{T}_{\text {con }}-\mathrm{T}_{i}\right)$

From eq. (7) $\mathrm{T}_{\text {con }}$ can be represented as

$\mathrm{T}_{\text {con }}=\frac{\mathrm{T}_{\mathrm{i}}+\mathrm{PT}_{\mathrm{hp}}}{1+\mathrm{P}}$

Where:

$\mathrm{P}=\frac{\mathrm{A}_{\mathrm{hp}} \mathrm{U}_{h p}}{\mathrm{~A}_{\text {con }} \mathrm{U}_{\text {con }}}$

The over-all condenser heat transfer coefficient can be calculated as:

$U_{\text {con }}=\frac{1}{\frac{t_{p}}{K_{p}}+\frac{1}{h_{\text {con }}}}$

$\mathrm{h}_{\mathrm{con}}$ is the heat transfer coefficient between the outside wall surface of the condenser section and the water flow in the heat exchanger, it can be calculated as follows:

$\mathrm{h}_{\mathrm{con}}=\left(\mathrm{Nu} * \mathrm{~K}_{\mathrm{w}}\right) / \mathrm{D}_{\mathrm{h}}$

$\mathrm{D}_{h}=\mathrm{D}_{i}-\mathrm{d}_{o}$

According to the assumptions that the flow inside the heat exchanger is considered fully developed laminar flow. Also inside the condenser section, and the flow may be assumed thermally developed at constant heat flux condition. In conclusion Nusselt No. was given as constant value equal to [10]:

$\mathrm{Nu}=48 / 11$

Figure (1) shows the single HP absorber plate with heat exchanger, the evaporator section the condenser section and the movement of the cooling water are also illustrated in this figure. 


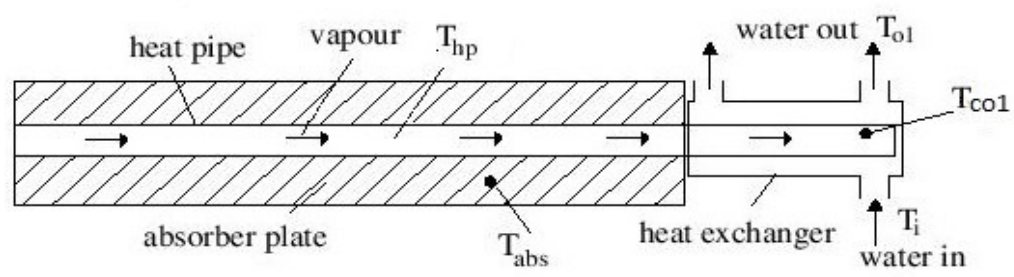

Figure (1) Single heat pipe absorber with heat exchanger

The useful heat is the amount of heat energy which results from the differences between the heat energy absorbed and the heat energy lost to the ambient. The useful heat can be modeled according to the Hottel_Willer equation [12]:

$\mathrm{Qu}=A_{a 1} \mathrm{~F}_{R}\left[H_{t}(\tau \alpha)-\mathrm{U}_{c}\left(\mathrm{~T}_{\mathrm{hp}}-\mathrm{T}_{a}\right)\right]$

It can be assumed that all the useful heat transferred through the HP which is extracted to the cooling fluid flowing in the heat exchanger, it can be written as follows:

$\mathrm{Q}_{u 1}=\dot{\mathrm{m}} \mathrm{Cp}\left(\mathrm{T}_{\mathrm{o} 1}-\mathrm{T}_{i}\right)$

Equating Eq. (13) and Eq.(14) and by the simplification. The result is:

$\mathrm{T}_{\mathrm{hp}}=\mathrm{T}_{a}+\frac{\mathrm{H}_{t}(\tau \alpha)}{\mathrm{U}_{c}}-\frac{\mathrm{T}_{\mathrm{o} 1}-\mathrm{T}_{i}}{(\mathrm{ntu})_{\mathrm{hp}}}$

$(\mathrm{ntu})_{\mathrm{hp}}=\frac{\mathrm{FrAa}_{\mathrm{U}} \mathrm{U}_{\mathrm{c}}}{\dot{\mathrm{m} C p}}$

The vapour in the HP is almost at constant temperature because that the condensation and boiling heat transfer occurs at constant saturation temperature. Therefore its specific heat and capacity rate will be equal to infinity. Then as a consequence the capacity ratio will be equal to zero, therefore, the equation of effectiveness can be written as[13]:

$\varepsilon_{1}=1-\mathrm{e}^{(-\mathrm{ntu})}$ con

$(\mathrm{ntu})_{\mathrm{con} \cdot}=\frac{\mathrm{A}_{\mathrm{con}} \mathrm{U}_{\mathrm{con}}}{(\dot{\mathrm{m} C p})}$

Effectiveness in general form is :

$\varepsilon_{1}=\frac{(T o 1-T i)}{\left(T_{c o n}-T_{i}\right)}$

From the above equation. $\mathrm{T}_{01}$ can be calculated as:

$\mathrm{T}_{\mathrm{o} 1}=\mathrm{Ti}+\varepsilon_{1}\left(\mathrm{~T}_{\text {con }}-\mathrm{T}_{\mathrm{i}}\right)$

By substituting eq. (8) in eq.(21), the outlet condenser temperature from the first HP heat exchanger can be calculated as:

$\mathrm{T}_{o 1}=\mathrm{T}_{i}+\varepsilon_{1} \frac{P}{(1+P)}\left(T_{h p}-T_{i}\right)$

By substituting the value of $\mathrm{T}_{01}$ from. (22) into equation (15), the HP temperature can be modified to the following form as shown in eq (23):

$\mathrm{T}_{\mathrm{hp}}=\frac{\frac{\mathrm{H}_{\mathrm{t}}(\tau \alpha)}{\mathrm{U}_{\mathrm{c}}}+\mathrm{T}_{\mathrm{a}}+\frac{\mathrm{Ti \varepsilon 1}}{(\mathrm{nitu}) \mathrm{hp}}\left(\frac{\mathrm{P}}{(1+\mathrm{P})}\right)}{1+\frac{\varepsilon 1}{(\mathrm{ntu}) \mathrm{hp} 1}\left(\frac{\mathrm{p}}{(1+\mathrm{p})}\right)}$ 
In the case of flat plate solar collector with n number of HPs eq. (22) can be modified to the form shown below:

$\mathrm{T}_{\mathrm{o}}(\mathrm{n})=\mathrm{T}_{\mathrm{o}}(\mathrm{n}-1)+\varepsilon \mathrm{n} \frac{\mathrm{P}}{(1+\mathrm{P})}\left(\mathrm{T}_{\mathrm{hp}}(\mathrm{n})-\mathrm{T}_{\mathrm{o}}(\mathrm{n}-1)\right)$

The cooling water gives off from the end of the heat exchanger which overlap with theHP array at a temperature higher than the inlet temperature, it can be represented as:

$\mathrm{T}_{\mathrm{o}}=\mathrm{T}_{\mathrm{i}}+\mathrm{E} \frac{\mathrm{P}}{(1+\mathrm{P})}\left(\mathrm{T}_{\mathrm{hp}}-\mathrm{T}_{\mathrm{i}}\right)$

The overall effectiveness of $n$ number of condensers can be written as[11]:

$1-E=\left(1-\varepsilon_{1}\right)\left(1-\varepsilon_{2}\right)\left(1-\varepsilon_{3}\right) \ldots . .(1-\varepsilon n)$

For equal values of effectiveness eq. (26) can be written as:

$\mathrm{E}=1-(1-\varepsilon)^{n}$

The average temperature of HP can be calculated as:

$\mathrm{T}_{\mathrm{hp}}=\frac{\frac{\mathrm{H}_{\mathrm{t}}(\tau \alpha)}{\mathrm{U}_{\mathrm{c}}}+\mathrm{Ta}+\frac{\mathrm{TiE}}{(\mathrm{NTU}) \mathrm{hp}}\left(\frac{\mathrm{P}}{(1+\mathrm{P})}\right)}{1+\frac{\mathrm{E}}{(\mathrm{NTU}) \mathrm{hp}}\left(\frac{\mathrm{p}}{(1+\mathrm{p})}\right)}$

The number of transfer unit for $\mathrm{n}$ number of HP and condenser section can be calculated as:

$$
\begin{aligned}
& (\mathrm{NTU})_{\mathrm{hp}}=\mathrm{n}(\mathrm{ntu})_{\mathrm{hp}} \\
& (\mathrm{NTU})_{\mathrm{con}}=\mathrm{n}(\mathrm{ntu})_{\mathrm{con}}
\end{aligned}
$$

The outlet water temperature $(\mathrm{eq}(25))$ can be used to calculate the the collector theoretical efficiency as follow:

$\eta_{\text {theo }}=\frac{\dot{\mathrm{m} c p}\left(\mathrm{~T}_{\mathrm{o}}-\mathrm{T}_{\mathrm{i}}\right)}{\mathrm{H}_{t} \mathrm{~A}_{\mathrm{c}}}$

\section{3- Experimental Set up.}

The FPHPSC is shown in Figure (2) which consisted of copper absorber plate of $(155 \mathrm{~cm}$ length, $100 \mathrm{~cm}$ width and $0.1 \mathrm{~cm}$ thickness), single glass cover of $0.6 \mathrm{~cm}$ thickness, glass wool insulation and aluminum case. Ten wickless HPs of $12.7 \mathrm{~mm}$ inner diameter, and $185 \mathrm{~cm}$ length $1.34 \mathrm{~cm}$ outer diameter length (155 $\mathrm{cm}$ represent the evaporator section and $30 \mathrm{~cm}$ represent the condenser section ) are welded on the surface of the absorber plate by using silver welding filler they together painted with black paint. Closed loop system was designed and connected with the solar collector to obtain test result. This loop is an auxiliary system consisted of water storage tank, water pump, water filter, stand of the tank and piping network. The measuring tools used in this work are digital thermocouples type K, thermocouples type K, thermocouple reader, selector switches, digital solar power meter, hot wire anemometer. 


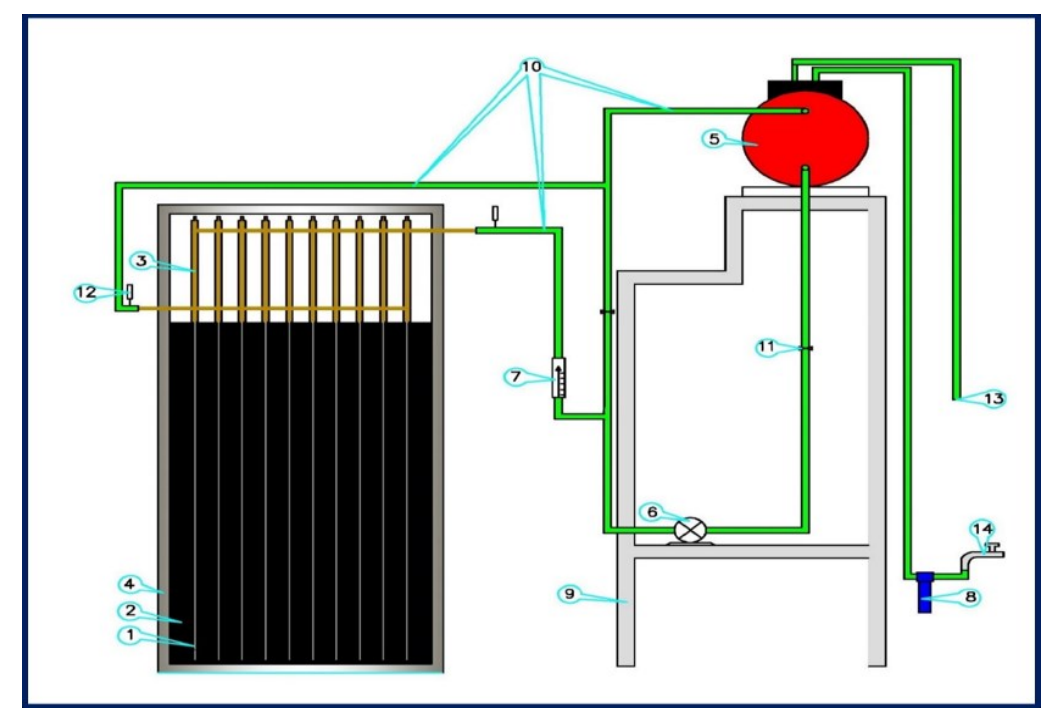

Figure (2) schematic diagram of the heat pipe solar collector system.

Where:

1-HP tube 2-absorber plate 3-heat exchanger 4- collector case 5-Water storage tank 6- circulation pump 7- flow meter 8- water filter 9-Stand of tank 10-piping system 11-control valves 12-digital thermocouple13- water drainage pipe 14- feed water pipe

\section{4-Results and Discussion:}

The variation of CWMFR with the instantaneous efficiency during the local time for different values of the collector tilt angle is shown in figure (3). It is intelligible from the figure that the efficiency of the HPSC is increased with increasing the value of CWMFR, the overall collector efficiency is $70.64 \%$ at $0.03 \mathrm{~kg} / \mathrm{s}$ CWMFR, while it is $82.87 \%$ at $0.06 \mathrm{~kg} / \mathrm{s}$ CWMFR with the same collector tilt angle $\left(45^{\circ}\right)$. The increment in the efficiency values was occurred because that the high CWMFR draws large amount of heat from the condenser section. That means enhancement of useful energy gain. Also the rate of the evaporation and condensation heat transfer processes inside the container of the HP is accelerated, this leads to make the working fluid to transfer large amount of heat between evaporator and condenser section of the HP. The final objective of this process is to increase the useful energy heat gain and collector efficiency. The increasing of the CWMFR avoids raising the temperature and pressure inside the HP which reduces it's temperature and then reduces the losses which in turn enhances the efficiency of the collector.

As the cooling water mass flow rates through the collector increase the velocity of water increased which leads to reduce the temperature differences between the inlet and the outlet water sections.

Figure (4) shows the variation of the collector efficiency and the amount of useful heat with the solar intensity along the solar time at different values of cooling water mass flow rates at $45^{\circ}$ collector tilt angle. Generally, it is clear from the figures that the useful energy curves behave similar to the solar intensity curves. It also obvious from the figures that the collector efficiency decrease at midday (for clear days). This is due to the fact that the solar intensity reach its highest values at midday, which increases the 
temperature of the absorber plate that means higher energy losses to the ambient and less collector efficiency according to collector efficiency equation $\left(\eta=Q_{\text {useful }} / H_{t} * A_{c}\right)$. It also can be shown from figures that almost the collector efficiencies have higher values at the beginning and the end of the experiments because at these times the solar intensity has rather small values that make the temperature of the absorber plate low which conduces to lower losses and higher energy gain and eventually to higher efficiency

The comparison is made between the theoretical and experimental instantaneous efficiency for different values of cooling water mass flow rates. Figure (5) shows the validation between the results. The overall efficiency differences between the experimental and theoretical efficiencies are (3.286\%). The comparison results of the shows acceptable values with good agreement.

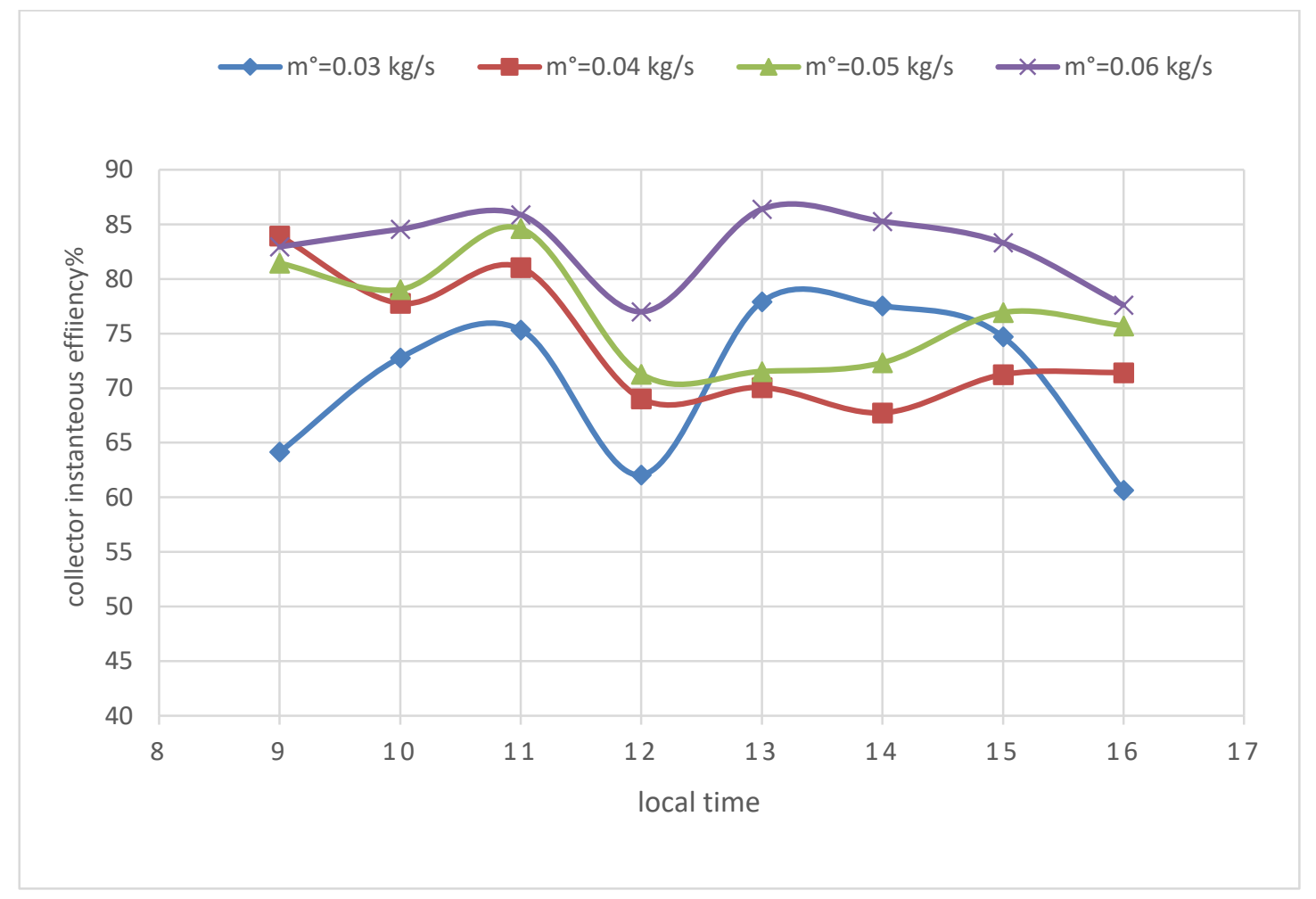

Figure (3) variation of collector instantaneous efficiency with the solar time at different cooling water mass flow rates at $45^{\circ}$ collector tilt angle. 

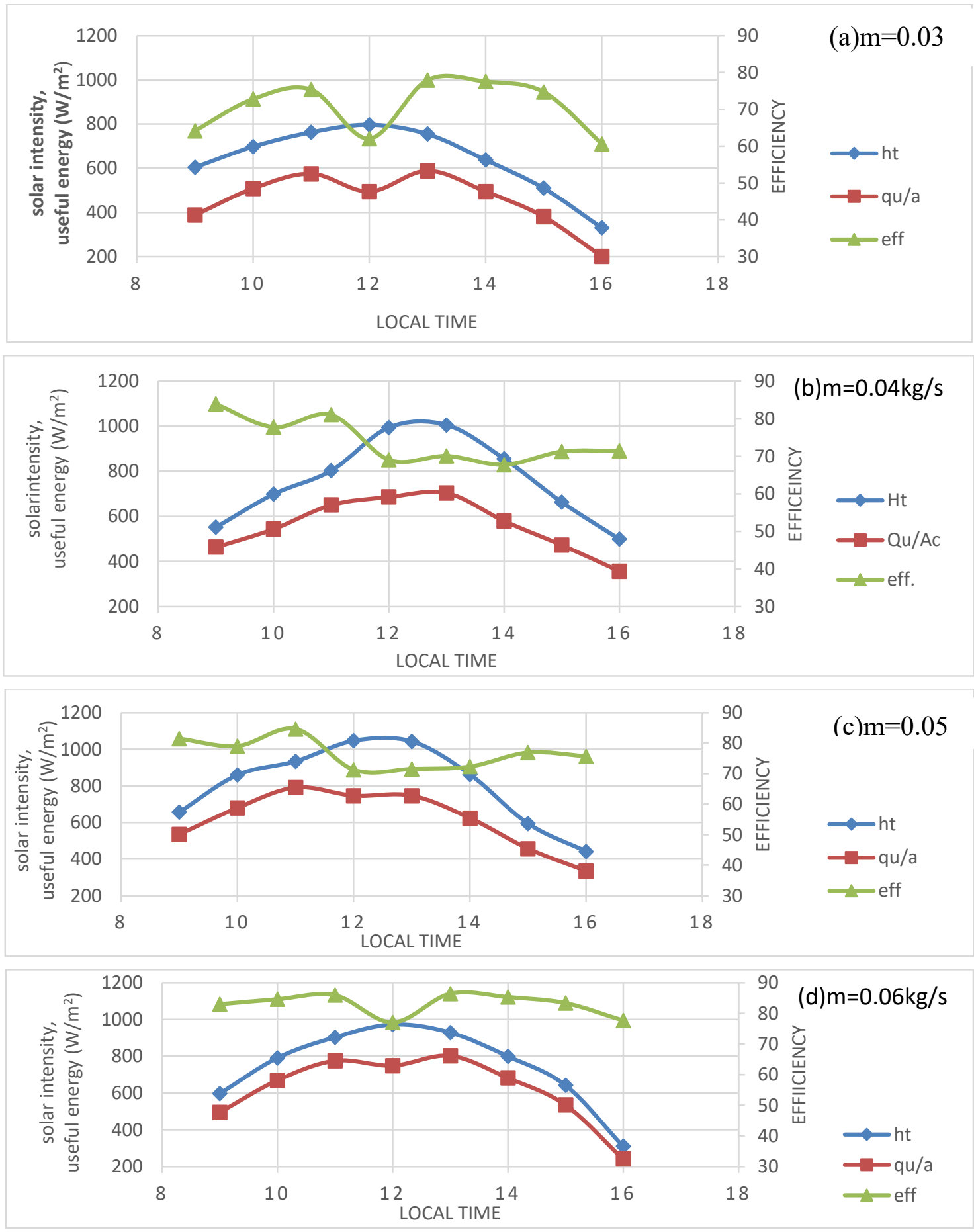

Figure (4) variation of instantaneous efficiency, amount of useful heat and solar intensity with the solar time at different mass flow rates. 


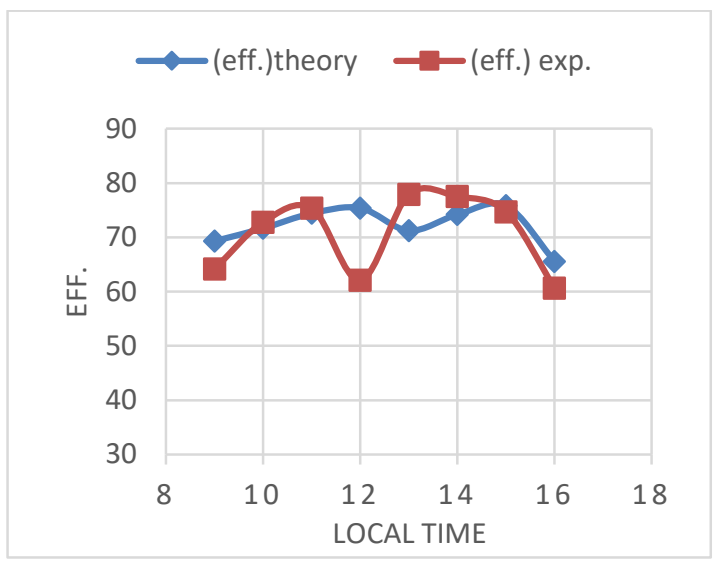

(a)Mass flow rate $=0.03 \mathrm{~kg} / \mathrm{s}$

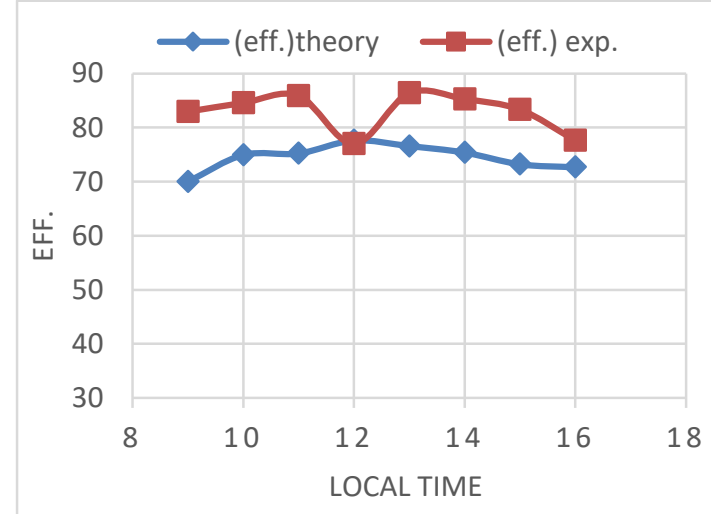

(d)Mass flow rate $=0.06 \mathrm{~kg} / \mathrm{s}$

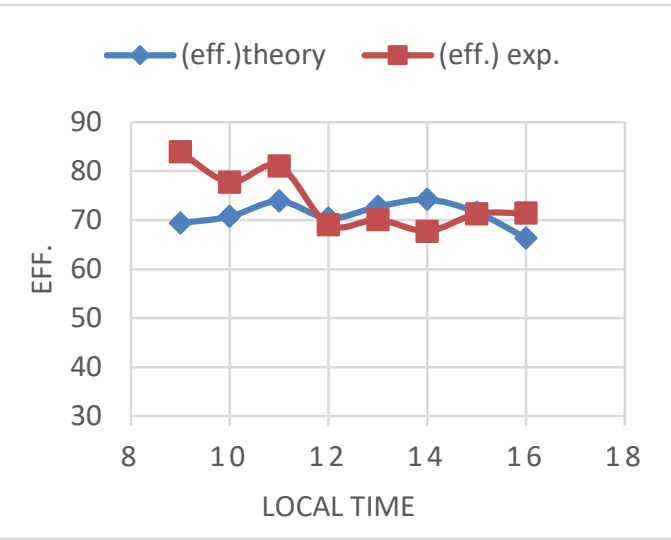

(b) Mass flow rate $=0.04 \mathrm{~kg} / \mathrm{s}$

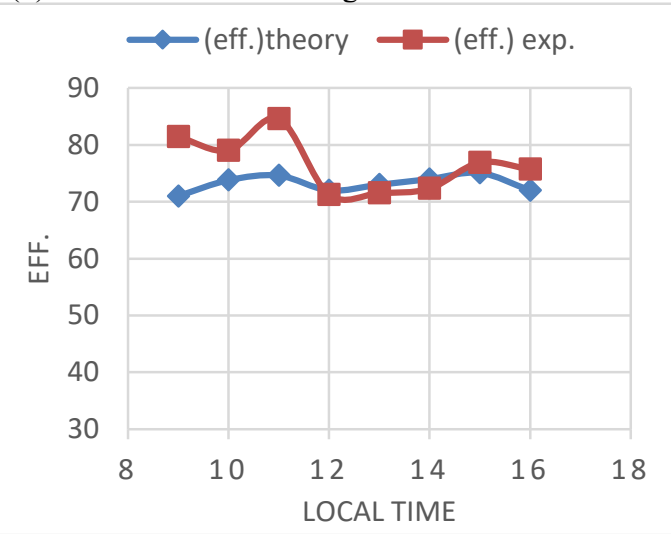

(c) Mass flow rate $=0.05 \mathrm{~kg} / \mathrm{s}$

Figure. (5) Comparison between experimental and theoretical efficiency at different mass flow rate.

\section{Conclusion:}

This work has been exhibited both experimental and theoretical study of the FPHPSC. It can be concluded from this work the following points:

1-The increasing of the CWMFR with constant tilt angle leads to increase in the amount of useful energy gain and eventually the collector efficiency (the increment in the efficiency of the collector is about $13 \%$ when the CWMFR has been increased from $0.03 \mathrm{~kg} / \mathrm{sec}$ to $0.06 \mathrm{~kg} / \mathrm{sec}$ ).

2-The solar radiation and the amount of useful energy gained and had the same profile during solar time.

3-The collector instantaneous efficiency has low values around midday time (for clear days), as compared to the efficiency values at the remaining time of the day.

\section{References:}

[1] David Reay and Peter Kew, "Heat Pipe Theory, Design and Application" International Journal of New York, Fifth Edition, 2006.

[2] Amir Faghri ,"Heat Pipes: Review, Opportunities and Challenges", Frontiers in heat pipes, 2014.

[3] Amir Faghri, "Heat Pipe Science and Technology", Taylor and Francis Group, First Edition, 1995. 
[4] Barhim Taofik, Mihiri Foued and Jemni Abdlmajid,"Parametric Study of Flat Plate Wick Assisted Heat Pipe Solar Collector", Journal of solar Energy Engineering, Vol. 135, 2013.

[5] Facao J. and Oliveira A. C. "Simulation of the Thermal Behavior of a Hybrid Heat Pipe Solar Collector" 1st International Conference on Sustainable Energy Technologies, Porto, Portugal, 2002.

[6] Samual L. A., Sergio C., Jaco F. and Almeida D. "Experimental Investigation of the Thermal Performance of Two Phase Closed Thermosyphns with Addition of A Liquid Retention Structure in the Evaporator Region",13 th. International Heat Pipe Conference, 2004.

[7] Nada S.A., El-Ghetany H.H. and Hussein H.M.S., "Performance of a Two Phase Closed Thermosyphon Solar Collector with a Sheel and Tube Heat Exchanger", Applied Thermal Engineering, 2004.

[8] Abede K.E.

"Numerical Modeling and Experimental Validation of Heat Pipe Solar Collector for Water Heating" M.Sc. thesis, KTH School of Industrial Engineering and Management Energy technology, 2012.

[9] Jalal M. J., Sabah T.A. AND Ahmed H.J., "Study the Effect of variable condensers Length on Improving the Performance of a Heat Pipe Solar Collector", Advances in Natural and Applied Sciences, 2016.

[10] S.B. Riffat, X. Zhao, P.S. Doherrty, "Developing of a theoretical model to investigate thermal performance of a thin membrane heat pipe solar collector", Journal of Applied Thermal Engineering, pp. 899-915.

[11] Azad. "Theoretical and Experimental Investigation of Heat Pipe Solar Collector", Experimental Thermal and Fluid Science, 2008.

[12] H.C. Hottel, A. Willier, "Evaluation of flat plate solar collector performance, in: Transactions of the Conference on Solar Energy", Vol. II, Thermal Processes, University Arizona, pp. 74-104, 1955.

[13] M.W. Kays, A.C. London, "Compact Heat Exchanger Design", McGraw-Hill, New York, Third Edition, 1984. 